\title{
PATHOGENICITY OF Macrophomina SPECIES COLLECTED FROM WEEDS IN COWPEA $^{1}$
}

\author{
RUI SALES JÚNIOR ${ }^{2 *}$, ALFREDO NOGUEIRA DA SILVA NETO ${ }^{2}$, ANDRÉIA MITSA PAIVA NEGREIROS ${ }^{2}$, \\ THOMAZ RAUAN RODRIGUES GOMES ${ }^{2}$, MÁRCIA MICHELLE DE QUEIROZ AMBRÓSIO ${ }^{2}$, JOSEP ARMENGOL ${ }^{3}$
}

\begin{abstract}
Charcoal rot caused by Macrophomina phaseolina is a major cowpea disease causing substantial losses to growers. In the semi-arid region of Brazil, cowpea is one of the most widely used alternatives for crop rotation during the off-season of melon. This favors Macrophomina multiplication because both crops are hosts of this pathogen. The objective of this study was to verify the pathogenicity of Macrophomina phaseolina and M. pseudophaseolina on cowpea. The Macrophomina spp. isolates used were obtained from the roots of Trianthema portulacastrum and Boerhavia diffusa, weed species prevalent in melon production areas in North-east Brazilian. The experiment was carried out in a greenhouse. Cowpea plants cv. 'Paulistinha' were inoculated with $30 \mathrm{M}$. phaseolina isolates, $30 \mathrm{M}$. pseudophaseolina isolates and a reference isolate of $M$. phaseolina obtained from cowpea roots. All Macrophomina isolates were able to cause disease on cowpea and there were no statistical differences between both Macrophomina species regarding disease incidence and severity. Moreover, 65.2 and $100.0 \%$ of the M. phaseolina isolates, and 56.2 and $92.8 \%$ of the M. pseudophaseolina isolates, obtained from $T$. portulacastrum and B. diffusa, respectively, were as severe to cowpea as the $M$. phaseolina reference isolate from cowpea. These results emphasize the need to establish management practices aiming to control $T$. portucalastrum and $B$. diffusa from cowpea production areas, as they can act as potential sources of inoculum and survival for Macrophomina spp.
\end{abstract}

Keywords: Boerhavia diffusa. Inoculation. Soil-borne pathogen. Trianthema portulacastrum. Vigna unguiculata.

\section{PATOGENICIDADE DE ESPÉCIES DE Macrophomina COLETADAS DE PLANTAS DANINHAS EM FEIJÃO-CAUPI}

RESUMO - A podridão de carvão causada por Macrophomina phaseolina é uma das principais doenças do feijão-caupi, causando perdas substanciais para os produtores. Na região semiárida do Brasil, o feijão-caupi é uma das alternativas utilizadas para rotação de culturas durante a entressafra do melão. Isso favorece a multiplicação de Macrophomina, uma vez que ambas as culturas são hospedeiras desse patógeno. O objetivo deste estudo foi verificar a patogenicidade em caupi de Macrophomina phaseolina e M. pseudophaseolina em caupi. Isolados de Macrophomina spp. obtidos das raízes de Trianthema portulacastrum e Boerhavia diffusa, espécies de plantas daninhas prevalentes em áreas de produção de melão no Nordeste brasileiro foram utilizadas neste estudo. O experimento foi realizado em casa de vegetação. Plantas de feijão-caupi 'Paulistinha' foram inoculados com 30 isolados de M. phaseolina, 30 isolados de M. pseudophaseolina e um isolado de referência de $M$. phaseolina obtido de raízes de feijão-caupi. Todos os isolados de Macrophomina foram patogênicos ao feijão-caupi, não havendo diferenças estatísticas entre as duas espécies de Macrophomina em relação à incidência e severidade da doença. Além disso, 65,2 e 100,0\% dos isolados de M. phaseolina, e 56,2 e $92,8 \%$ dos isolados de M. pseudophaseolina, obtidos de $T$. portulacastrum e B. diffusa, respectivamente, foram tão severos ao feijão-caupi quanto o isolado de referência. Esses resultados enfatizam a necessidade de estabelecer práticas de manejo visando o controle de $T$. portucalastrum e B. diffusa nas áreas de produção de feijão-caupi, pois podem atuar como fontes de inóculo e sobrevivência para Macrophomina spp.

Palavras-chave: Boerhavia diffusa. Inoculação. Patógeno habitante do solo. Trianthema portulacastrum. Vigna unguiculata.

\footnotetext{
"Corresponding author

${ }^{1}$ Received for publication in $10 / 17 / 2019$; accepted in $02 / 13 / 2020$.

Paper extracted from the dissertation of the second author.

${ }^{2}$ Department of Agronomic and Forest Sciences, Universidade Federal Rural do Semi-Árido, Mossoró, RN, Brazil; jrrui@hotmail.com ORCID: 0000-0001-9097-0649, feumsn@hotmail.com - ORCID: 0000-0002-4080-7162, deia-mitsa@hotmail.com - ORCID: 0000-00029544-2527, thomas-rauan@hotmail.com - ORCID: 0000-0003-3868-7904, marciamichelle@ufersa.edu.br - ORCID: 0000-0002-50339745.

${ }^{3}$ Mediterranean Agroforestry Institute, Universitat Politècnica de València, Valencia, Spain; jarmengo@eaf.upv.es - ORCID: 0000-0003$3815-8578$.
} 


\section{INTRODUCTION}

Cowpea (Vigna unguiculata [L.] Walp.) is one of the main legumes cultivated in semi-arid regions of African countries, with $95.9 \%$ of world production (7.1 million tons) (FAOSTAT, 2019). However, world production is underestimated because countries such as Brazil and India do not have separate production data between cowpea and common bean (Phaseolus vulgaris L.) (DAMASCENO-SILVA; ROCHA; MENEZESJÚNIOR, 2016).

In Brazil, cowpea production is concentrated mainly in the North- east and North Regions, with increasing progress in the Midwest region. This crop is considered one of the main protein sources of human food, and an important generator of employment and income in the growing regions (ROCHA et al., 2009; DAMASCENO-SILVA; ROCHA; MENEZES-JÚNIOR, 2016). The importance of cowpea is also due to the possibility of being cultivated by small farmers in family farms under irrigated and rainfed conditions, due to its easy management and low production costs, playing an important socioeconomic role (RAMOS et al., 2012; DAMASCENO-SILVA; ROCHA; MENEZESJÚNIOR, 2016).

It is estimated that in the $2016 / 17$ growing season, Brazilian cowpea production reached 789.8 thousand tons in 1.5 million hectares (CONAB, 2019).

Fungal diseases are among the most important limiting factors for cowpea production in Brazil, being responsible for high qualitative and quantitative losses. "Charcoal rot" caused by Macrophomina phaseolina (Tassi) Goid. (RIOS, 1988) is among the most relevant diseases of cowpea crops in Brazil. Due to the thermotolerant condition of this fungus, this disease becomes even more important in the North-east Brazilian Region, as climatic conditions such as high temperature and low humidity favor its development (ATHAYDE SOBRINHO, 2016; GOMES-SILVA et al., 2017; NEGREIROS et al., 2019b).

The primary source of inoculum for $M$. phaseolina are soil microsclerotia, infected seeds, and crop debris (KAUR et al., 2012; REIS; BOARETTO; DANELLI, 2014). Microsclerotia can survive for long periods, about 2 to 15 years, and can germinate throughout the growing season (GUPTA; SHARMA; RAMTEKE, 2012).

A study conducted in Senegal with Macrophomina isolates from Abelmoschus esculentus (L.) Moench., Arachis hypogaea L., Hibiscus sabdariffa L., and cowpea plants, identified a new species of Macrophomina named $M$. pseudophaseolina Crous, Sarr \& Ndiaye (SARR et al., 2014). In Brazil, recent studies have reported the occurrence of three species of Macrophomina: $M$. phaseolina, affecting numerous crops, among them cowpea; $M$. pseudophaseolina affecting $A$. hypogaea, Gossypium hirsutum L. and Ricinus communis L.; and M. euphorbiicola A.R. Machado, D.J. Soares \& O.L. Pereira, sp. nov. a new species, affecting Jatropha gossypiifolia L. and $R$. communis plants (MACHADO et al., 2019). Negreiros et al. (2019b) studying phytopathogenic fungi present in roots of prevalent weeds in melon fields in the states of Rio Grande do Norte (RN) and Ceará (CE) (North -east Brazilian Region) reported the occurrence of these three Macrophomina species in Trianthema portucalastrum L. and Boerhavia diffusa L. Very recently, Zhao et al. (2019) reported a novel Macrophomina species, M. vaccinii Y. Zhang ter \& L. Zhao, sp. nov. affecting Vaccinium spp. in China.

This study aims to verify the pathogenicity of M. phaseolina and M. pseudophaseolina isolates obtained from roots of the weed species $T$. portulacastrum and B. diffusa on cowpea.

\section{MATERIALS AND METHODS}

\section{Macrophomina spp. Isolates}

The experiment was carried out in a greenhouse from December 2016 to March 2017 to evaluate the pathogenicity of 61 isolates of two Macrophomina species on cowpea. These isolates were obtained from asymptomatic $T$. portulacastrum and $B$. diffusa weed roots collected from commercial melon (Cucumis melo L.) and watermelon (Citrullus lanatus [Thunb.] Matsum \& Nakai) production areas in the municipalities of Icapuí (CE), Assú and Mossoró (RN). Crop rotations in these areas include cowpea.

In the experiment, $30 \mathrm{M}$. phaseolina isolates (23 from $T$. portulacastrum and 7 from $B$. diffusa), $30 M$. pseudophaseolina isolates (16 from $T$. portulacastrum and 14 from $B$. diffusa) and one reference isolate from $M$. phaseolina obtained from cowpea roots (Strain number: MFE-01, collected in 2013, location: Brazil, Rio Grande do Norte, Mossoró, GenBank accession number: MN136201) were used (Table 1).

The identity of the fungal isolates used in this experiment was molecularly confirmed (NEGREIROS et al., 2019b), and a copy of each was deposited in the "Profa. Maria Menezes" (CMM) fungi collection, at the Universidade Federal Rural de Pernambuco (Pernambuco, Recife, Brazil) (Table 1). 
R. SALES JÚNIOR et al.

Table 1. List of isolates used in the pathogenicity test of Macrophomina species.

\begin{tabular}{|c|c|c|c|c|c|}
\hline \multicolumn{3}{|c|}{ Macrophomina pseudophaseolina } & \multicolumn{3}{|c|}{ Macrophomina phaseolina } \\
\hline Strain number & Host & Location & Strain number & Host & Location \\
\hline CMM-4765 & $T p^{I}$ & Brazil - Icapuí & CMM-4749 & $T p$ & Brazil - Mossoró \\
\hline CMM-4766 & $T p$ & Brazil - Icapuí & CMM-4750 & $T p$ & Brazil - Mossoró \\
\hline CMM-4767 & $T p$ & Brazil - Icapuí & CMM-4751 & $T p$ & Brazil - Mossoró \\
\hline CMM-4768 & $T p$ & Brazil - Icapuí & CMM-4752 & $T p$ & Brazil - Mossoró \\
\hline CMM-4770 & $T p$ & Brazil - Assú & CMM-4753 & $T p$ & Brazil - Mossoró \\
\hline CMM-4772 & $T p$ & Brazil - Assú & CMM-4754 & $T p$ & Brazil - Mossoró \\
\hline CMM-4773 & $T p$ & Brazil - Assú & CMM-4755 & $T p$ & Brazil - Mossoró \\
\hline CMM-4774 & $T p$ & Brazil - Assú & CMM-4756 & $T p$ & Brazil - Mossoró \\
\hline CMM-4775 & $T p$ & Brazil - Assú & CMM-4757 & $T p$ & Brazil - Mossoró \\
\hline CMM-4777 & $T p$ & Brazil - Assú & CMM-4733 & $T p$ & Brazil - Icapuí \\
\hline CMM-4778 & $T p$ & Brazil - Assú & CMM-4734 & $T p$ & Brazil - Icapuí \\
\hline CMM-4779 & $T p$ & Brazil - Mossoró & CMM-4735 & $T p$ & Brazil - Icapuí \\
\hline CMM-4780 & $T p$ & Brazil - Mossoró & CMM-4736 & $T p$ & Brazil - Icapuí \\
\hline CMM-4784 & $T p$ & Brazil - Mossoró & CMM-4737 & $T p$ & Brazil - Icapuí \\
\hline CMM-4787 & $T p$ & Brazil - Mossoró & CMM-4738 & $T p$ & Brazil - Icapuí \\
\hline CMM-4788 & $T p$ & Brazil - Mossoró & CMM-4739 & $T p$ & Brazil - Icapuí \\
\hline CMM-4789 & $B d^{2}$ & Brazil - Assú & CMM-4740 & $T p$ & Brazil - Icapuí \\
\hline CMM-4792 & $B d$ & Brazil - Assú & CMM-4741 & $T p$ & Brazil - Icapuí \\
\hline CMM-4793 & $B d$ & Brazil - Assú & CMM-4742 & $T p$ & Brazil - Icapuí \\
\hline CMM-4794 & $B d$ & Brazil - Assú & CMM-4743 & $T p$ & Brazil - Icapuí \\
\hline CMM-4795 & $B d$ & Brazil - Assú & CMM-4746 & $T p$ & Brazil - Icapuí \\
\hline CMM-4796 & $B d$ & Brazil - Assú & CMM-4747 & $T p$ & Brazil - Icapuí \\
\hline CMM-4797 & $B d$ & Brazil - Assú & CMM-4748 & $T p$ & Brazil - Icapuí \\
\hline CMM-4806 & $B d$ & Brazil - Assú & CMM-4758 & $B d$ & Brazil - Assú \\
\hline CMM-4810 & $B d$ & Brazil - Assú & CMM-4759 & $B d$ & Brazil - Assú \\
\hline CMM-4811 & $B d$ & Brazil - Assú & CMM-4760 & $B d$ & Brazil - Assú \\
\hline CMM-4815 & $B d$ & Brazil - Mossoró & CMM-4761 & $B d$ & Brazil - Assú \\
\hline CMM-4817 & $B d$ & Brazil - Mossoró & CMM-4762 & $B d$ & Brazil - Mossoró \\
\hline CMM-4821 & $B d$ & Brazil - Mossoró & CMM-4763 & $B d$ & Brazil - Mossoró \\
\hline CMM-4826 & $B d$ & Brazil - Mossoró & CMM-4764 & $B d$ & Brazil - Mossoró \\
\hline- & - & - & MPH-FE & $V u^{3}$ & Brazil - Mossoró \\
\hline
\end{tabular}

${ }^{1}$ Trianthema portulacastrum $;{ }^{2}$ Boerhavia diffusa $;{ }^{3}$ Vigna unguiculata.

\section{Inoculum preparation}

All isolates were placed in potato-dextroseagar (PDA) culture medium and incubated at $28 \pm 2$ ${ }^{\circ} \mathrm{C}$ in the dark for seven days to be used for inoculum preparation.

Cowpea plants were inoculated following the methodology of the infested toothpick (AMBRÓSIO et al., 2015). Toothpick tips $(1.5 \mathrm{~cm})$ were vertically inserted, with the sharp portion of the toothpicks facing upwards, on a filter paper with the same internal diameter as the Petri plate. Subsequently, these plates, properly closed, were autoclaved at $121{ }^{\circ} \mathrm{C}$ for $30 \mathrm{~min}$. PDA was then poured into these plates about $4 \mathrm{~mm}$ from the end of the toothpicks. After solidification of the culture medium, four 0.5 $\mathrm{mm}$ diameter discs with fungal structures (mycelium and sclerotia) were transferred to these plates, equidistantly distributed, and incubated for eight days in an incubator at $30 \pm 2{ }^{\circ} \mathrm{C}$, for complete colonization of the toothpicks.

\section{Experimental design and evaluation}

Three seeds of cowpea cultivar 'Paulistinha' were sown in plastic pots, with a capacity for $0.75 \mathrm{~L}$, containing commercial substrate Tropstrato $\mathrm{HT}^{\circledR}$. Then, they were autoclaved twice at $121{ }^{\circ} \mathrm{C}$ for one hour, with a $24 \mathrm{~h}$ interval in between. Eight days after sowing, thinning was performed to have only one plant per pot. At this moment, toothpicks previously infested with each fungal isolate were inserted into the main stem of the plant at a height of $0.5 \mathrm{~cm}$ from ground level. For the uninoculated control, only autoclaved toothpicks were used.

The experimental design was completely randomized, with 61 treatments (representing the isolates) with five replications each, and one uninoculated control. The experimental unit consisted of a plastic pot with a plant. The pots were kept in a greenhouse at an average temperature of $32{ }^{\circ} \mathrm{C}$ for 30 days, under natural daylight conditions, and irrigation was manually performed. The experiment was repeated.

The incidence and severity of the Macrophomina isolates were evaluated 30 days after inoculation. Disease incidence was determined by counting plants with symptoms of charcoal rot, and the data were transformed as a percentage (\%). To assess the severity of the disease, a scale proposed by Abawi e Pastor-Corrales (1990) was used, with modifications, where $1=$ no symptoms; $3=$ lesions 
limited to cotyledonary leaves; $5=$ progressing lesions from cotyledonary leaves up to $2 \mathrm{~cm}$ in the stem; $7=$ extensive lesions, presence of chlorosis and necrosis in leaves and stem; and $9=$ presence of pycnidia on stem and plant death.

After the evaluation, all plants were analyzed for fungal isolation to confirm Koch's Postulates. Fragments of the diseased areas were disinfested in a $1.5 \%$ sodium hypochlorite solution for $1 \mathrm{~min}$ and washed in sterile water. The disinfested fragments were placed in PDA-tetracycline $\left(0.05 \mathrm{~g} \mathrm{~L} \mathrm{~L}^{-1}\right)$ medium and incubated for five days at $30 \pm 2{ }^{\circ} \mathrm{C}$.

For each experiment, the preliminary ANOVA was performed to determine whether there were significant differences between the two repetitions of the experiments and whether the data could be combined. Severity and incidence results by isolates of M. phaseolina and M. pseudophaseolina were analyzed with the non-parametric Kruskal-
Wallis test at the probability level of $5 \%(\mathrm{p} \leq 0.05)$ using the Assistat software, version 7.7 (SILVA; AZEVEDO, 2016). Differences in severity and incidence caused by Macrophomina species were determined using Mann-Whitney test at the 5\% significance level using statistix v.9.0 (Analytical Software).

\section{RESULTS AND DISCUSSION}

All isolates of both Macrophomina species (M. phaseolina and M. pseudophaseolina) isolated from $T$. portulacastrum and $B$. diffusa caused disease on cowpea plants (Table 2). The results of both experiments were combined because there were no statistical differences between the two experiments $(\mathrm{p} \leq 0.05)$.

Table 2. Reaction of Vigna unguiculata cv. 'Paulistinha' to inoculation with isolates of Macrophomina spp

\begin{tabular}{|c|c|c|c|c|c|c|c|c|c|}
\hline \multicolumn{5}{|c|}{ Macrophomina phaseolina } & \multicolumn{5}{|c|}{ Macrophomina pseudophaseolina } \\
\hline \multirow[b]{2}{*}{ Isolates } & \multicolumn{2}{|c|}{ Disease Severity } & \multicolumn{2}{|c|}{ Disease Incidence } & \multirow[b]{2}{*}{ Isolates } & \multicolumn{2}{|c|}{ Disease Severity } & \multicolumn{2}{|c|}{ Disease Incidence } \\
\hline & Rank & Mean $^{\mathrm{c}}$ & Rank & $\begin{array}{c}\operatorname{Mean}^{\mathrm{c}} \\
(\%)\end{array}$ & & Rank & Mean $^{c}$ & Rank & $\begin{array}{c}\operatorname{Mean}^{\mathrm{c}} \\
(\%)\end{array}$ \\
\hline $\mathrm{CMM}-4733^{\mathrm{a}}$ & $44.2 \mathrm{ab}$ & 1.4 & $49.0 \mathrm{ab}$ & 20 & CMM-4765 & $35.9 \mathrm{a}$ & 1.4 & $40.5 \mathrm{ab}$ & 20 \\
\hline CMM-4734 $4^{\mathrm{a}}$ & $85.2 \mathrm{abc}$ & 3.8 & $81.0 \mathrm{ab}$ & 60 & CMM-4766 ${ }^{\mathrm{a}}$ & $90.4 \mathrm{abc}$ & 3.4 & $104.5 \mathrm{~b}$ & 100 \\
\hline CMM-4735 & $102.2 \mathrm{abc}$ & 3.8 & $113.0 \mathrm{~b}$ & 100 & $\mathrm{CMM}-4767^{\mathrm{a}}$ & $81.5 \mathrm{abc}$ & 3.0 & $104.5 \mathrm{~b}$ & 100 \\
\hline CMM-4736 & $67.4 \mathrm{abc}$ & 3.0 & $65.0 \mathrm{ab}$ & 40 & CMM-4768 & $47.3 \mathrm{ab}$ & 1.8 & $56.5 \mathrm{ab}$ & 40 \\
\hline CMM-4737 & $66.6 \mathrm{abc}$ & 2.2 & $81.0 \mathrm{ab}$ & 60 & $\mathrm{CMM}-4770^{\mathrm{a}}$ & $99.3 \mathrm{abc}$ & 3.8 & $104.5 \mathrm{~b}$ & 100 \\
\hline CMM-4738 & $55.4 \mathrm{ab}$ & 1.8 & $65.0 \mathrm{ab}$ & 40 & CMM-4772 & $47.3 \mathrm{ab}$ & 1.8 & $56.5 \mathrm{ab}$ & 40 \\
\hline CMM-4739 & $33.0 \mathrm{a}$ & 1.0 & $33.0 \mathrm{a}$ & 0 & $\mathrm{CMM}-4773^{\mathrm{a}}$ & $35.9 \mathrm{a}$ & 1.4 & $40.5 \mathrm{ab}$ & 20 \\
\hline CMM-4740 & 89.8 abc & 3.8 & $97.0 \mathrm{ab}$ & 80 & CMM-4774 ${ }^{\mathrm{a}}$ & $58.7 \mathrm{abc}$ & 2.2 & $72.5 \mathrm{ab}$ & 60 \\
\hline CMM- $4741^{\mathrm{a}}$ & $95.6 \mathrm{abc}$ & 3.4 & $113.0 \mathrm{~b}$ & 100 & $\mathrm{CMM}-4775^{\mathrm{a}}$ & $47.3 \mathrm{ab}$ & 1.8 & $56.5 \mathrm{ab}$ & 40 \\
\hline CMM-4742 & $62.0 \mathrm{abc}$ & 2.2 & $65.0 \mathrm{ab}$ & 40 & CMM-4777 & $70.1 \mathrm{abc}$ & 2.6 & $88.5 \mathrm{ab}$ & 80 \\
\hline CMM-4743 ${ }^{\mathrm{a}}$ & $44.2 \mathrm{ab}$ & 1.4 & $49.0 \mathrm{ab}$ & 20 & CMM-4778 & $95.2 \mathrm{abc}$ & 4.2 & $104.5 \mathrm{~b}$ & 100 \\
\hline CMM-4746 ${ }^{\mathrm{a}}$ & $56.2 \mathrm{ab}$ & 2.6 & $49.0 \mathrm{ab}$ & 20 & CMM-4779 & $47.3 \mathrm{ab}$ & 1.8 & $56.5 \mathrm{ab}$ & 40 \\
\hline CMM- $4747^{\mathrm{a}}$ & $106.7 \mathrm{abc}$ & 4.6 & $97.0 \mathrm{ab}$ & 80 & CMM-4780 & $65.1 \mathrm{abc}$ & 2.6 & $56.5 \mathrm{ab}$ & 40 \\
\hline CMM- $4748^{\mathrm{a}}$ & $91.0 \mathrm{abc}$ & 3.4 & $97.0 \mathrm{ab}$ & 80 & CMM-4784 & $24.5 \mathrm{a}$ & 1.0 & $24.5 \mathrm{a}$ & 0 \\
\hline CMM-4749 & 77.8 abc & 2.6 & $97.0 \mathrm{ab}$ & 80 & $\mathrm{CMM}-4787^{\mathrm{a}}$ & $67.6 \mathrm{abc}$ & 3.0 & $56.5 \mathrm{ab}$ & 40 \\
\hline CMM-4750 & $90.6 \mathrm{abc}$ & 4.6 & $81.0 \mathrm{ab}$ & 60 & CMM-4788 & $44.8 \mathrm{ab}$ & 1.8 & $40.5 \mathrm{ab}$ & 20 \\
\hline CMM-4751 ${ }^{\mathrm{a}}$ & $62.0 \mathrm{abc}$ & 2.2 & $65.0 \mathrm{ab}$ & 40 & CMM-4789 & $113.0 \mathrm{abc}$ & 5.0 & $104.5 \mathrm{~b}$ & 100 \\
\hline CMM-4752 & $56.2 \mathrm{ab}$ & 2.6 & $49.0 \mathrm{ab}$ & 20 & CMM-4792 & $104.1 \mathrm{abc}$ & 4.6 & $104.5 \mathrm{~b}$ & 100 \\
\hline CMM- $4753^{\mathrm{a}}$ & $84.8 \mathrm{abc}$ & 3.8 & $81.0 \mathrm{ab}$ & 60 & CMM-4793 ${ }^{\mathrm{b}}$ & $81.5 \mathrm{abc}$ & 3.0 & $104.5 \mathrm{~b}$ & 100 \\
\hline CMM-4754 ${ }^{\mathrm{a}}$ & $73.2 \mathrm{abc}$ & 2.6 & $81.0 \mathrm{ab}$ & 60 & CMM-4794 & $81.5 \mathrm{abc}$ & 3.0 & $104.5 \mathrm{~b}$ & 100 \\
\hline CMM-4755 & $56.2 \mathrm{ab}$ & 2.6 & $49.0 \mathrm{ab}$ & 20 & CMM-4795 & $108.2 \mathrm{abc}$ & 4.2 & $104.5 \mathrm{~b}$ & 100 \\
\hline CMM-4756 ${ }^{\mathrm{a}}$ & $33.0 \mathrm{a}$ & 1.0 & $33.0 \mathrm{a}$ & 0 & CMM-4796 & $58.7 \mathrm{abc}$ & 2.2 & $72.5 \mathrm{ab}$ & 60 \\
\hline CMM-4757 & $71.7 \mathrm{abc}$ & 3.0 & $65.0 \mathrm{ab}$ & 40 & CMM-4797 & $117.8 \mathrm{bc}$ & 5.8 & $104.5 \mathrm{~b}$ & 100 \\
\hline CMM-4758 & $101.0 \mathrm{abc}$ & 4.2 & $113.0 \mathrm{~b}$ & 100 & CMM-4806 & $135.6 \mathrm{bc}$ & 6.6 & $104.5 \mathrm{~b}$ & 100 \\
\hline CMM-4759 & $95.6 \mathrm{abc}$ & 3.4 & $113.0 \mathrm{~b}$ & 100 & CMM- $4810^{\mathrm{b}}$ & $133.3 \mathrm{bc}$ & 6.2 & $104.5 \mathrm{~b}$ & 100 \\
\hline CMM-4760 & $77.8 \mathrm{abc}$ & 2.6 & $97.0 \mathrm{ab}$ & 80 & CMM-4811 ${ }^{\mathrm{b}}$ & $47.3 \mathrm{ab}$ & 1.8 & $56.5 \mathrm{ab}$ & 40 \\
\hline CMM-4761 ${ }^{\mathrm{b}}$ & $135.3 \mathrm{bc}$ & 7.0 & $113.0 \mathrm{~b}$ & 100 & CMM- $4815^{\mathrm{b}}$ & $150.0 \mathrm{c}$ & 9.0 & $104.5 \mathrm{~b}$ & 100 \\
\hline CMM-4762 ${ }^{\mathrm{b}}$ & $119.6 \mathrm{abc}$ & 5.8 & $113.0 \mathrm{~b}$ & 100 & CMM- $4817^{\mathrm{b}}$ & $131.5 \mathrm{bc}$ & 7.0 & $104.5 \mathrm{~b}$ & 100 \\
\hline CMM-4763 ${ }^{\mathrm{b}}$ & $146.1 \mathrm{bc}$ & 8.6 & $113.0 \mathrm{~b}$ & 100 & CMM-4821 & $99.3 \mathrm{abc}$ & 3.8 & $104.5 \mathrm{~b}$ & 100 \\
\hline CMM-4764 & $114.2 \mathrm{abc}$ & 5.0 & $113.0 \mathrm{~b}$ & 100 & CMM- $4826^{\mathrm{b}}$ & $81.5 \mathrm{abc}$ & 3.0 & $104.5 \mathrm{~b}$ & 100 \\
\hline MPH-FE & $149.0 \mathrm{c}$ & 9.0 & $113.0 \mathrm{~b}$ & 100 & MPH-FE & $150.0 \mathrm{c}$ & 9.0 & $104.5 \mathrm{~b}$ & 100 \\
\hline Control & $33.0 \mathrm{a}$ & 1.0 & $33.0 \mathrm{a}$ & 0 & Control & $24.5 \mathrm{a}$ & 1.0 & $24.5 \mathrm{a}$ & 0 \\
\hline $\mathrm{H}_{\text {estatistic }}$ & 77.5 & & 70.1 & & $\mathrm{H}_{\text {estatistic }}$ & 107.4 & & 88.9 & \\
\hline
\end{tabular}

$\mathrm{H}_{\text {statistic }}$ value significant at $5 \%$ by Kruskal-Wallis test. ${ }^{\mathrm{a}}$ Isolates obtained from Trianthema portulacastrum; ${ }^{\text {b Isolates }}$ obtained from Boerhavia diffusa ${ }^{\mathrm{c}}$ Mean of 10 inoculated plants.

For both analyzed variables, incidence and disease severity, there were no statistical differences between the Macrophomina species for MannWhitney test $(\mathrm{p} \leq 0.05)$ (Figure 1). 

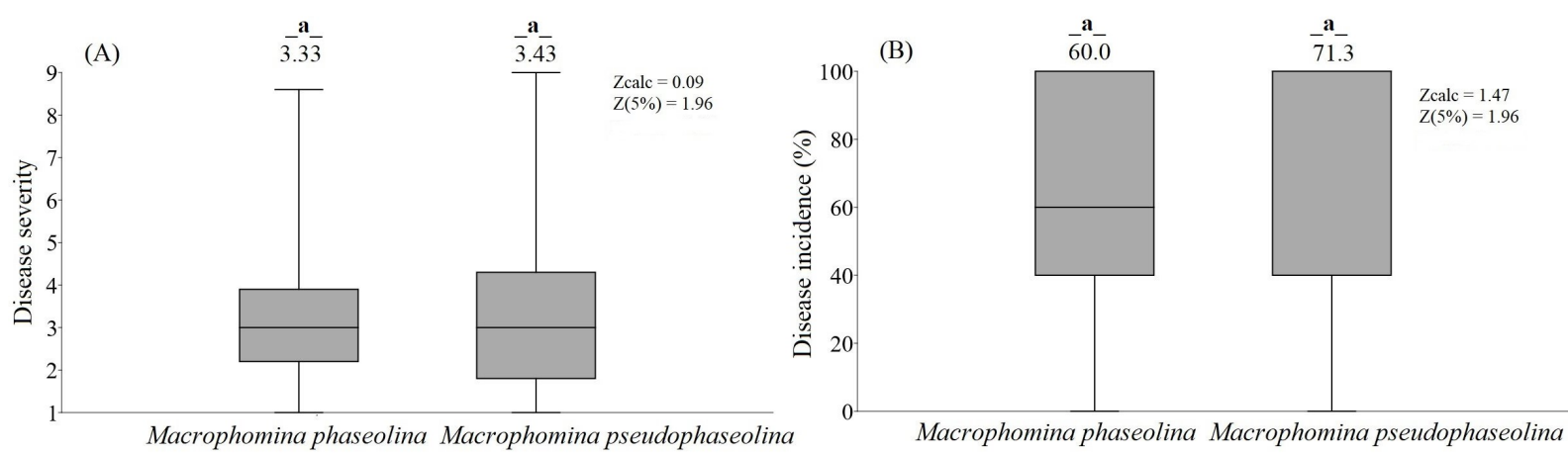

Figure 1. Boxplots showing (A) Disease Severity and (B) Incidence of the Macrophomina species in cowpea plants. The boxes show the first and third quartiles. Bold horizontal line represents median of group. Lower and upper whiskers extend from the boxes to the extreme values. Different lowercase letters indicate significant differences according to MannWhitney test $(\mathrm{p} \leq 0.05)$.

Noronha; Damasceno-Silva and Silva (2012) analyzed the genetic resistance of 35 cowpea genotypes to M. phaseolina and concluded that none of the genotypes showed resistance to the pathogen. Regarding M. pseudophaseolina, studies conducted by Sarr et al. (2014) reported that this species was able to damage different crops, among them cowpea, in Senegal. Subsequent pathogenicity studies of $M$. phaseolina and $M$. pseudophaseolina isolates, conducted by Ndiaye et al. (2015) on three varieties of cowpea under two temperature regimes (24-34 and $26-36{ }^{\circ} \mathrm{C}$ ) in a climatic chamber, showed that there were small differences in pathogenicity between $M$. phaseolina and $M$. pseudophaseolina. These authors indicated that the latter Macrophomina species seemed somewhat more aggressive in the susceptible cv. 'Mouride' (more microsclerotia per gram tissue and less biomass production) at the higher temperature tested $\left(26-36^{\circ} \mathrm{C}\right)$.

This fact is quite worrying, given that the production of this crop is prevalent in the Northeast and North regions of Brazil, where temperatures are quite high throughout the year. In fact, $M$. phaseolina is considered economically important in subtropical regions and tropical countries with a semiarid climate (ATHAYDE SOBRINHO, 2016; GOMES-SILVA et al., 2017; NEGREIROS et al., $2019 \mathrm{~b}$ ), but there is a lack of knowledge about the risks posed by $M$. pseudophaseolina on cowpea and other crops, because of its recent description (SARR et al., 2014).

In Brazil, M. phaseolina was first reported in 1935, infecting common bean plants in Campinas-SP (BITANCOURT, 1935). In cowpea, under favorable environmental conditions, this fungus can be highly virulent, attacking from the seed to the pod of the plant. Athayde Sobrinho, Viana and Santos (2005) detected the presence of $M$. phaseolina in $62 \%$ of cowpea seed samples analyzed in Brazil. According to Dhingra and Sinclair (1978), infected seeds, symptomatic or asymptomatic, represent the main form of spread of this fungus over long distances.

It is also important to note that 65.2 and $100.0 \%$ of the M. phaseolina isolates, and 56.2 and $92.8 \%$ of the $M$. pseudophaseolina isolates, obtained from $T$. portulacastrum and $B$. diffusa, respectively, were as severe to cowpea as the $M$. phaseolina reference isolate from cowpea (Table 2).

Although both Macrophomina species isolated from $T$. portulacastrum and $B$. diffusa were pathogenic to cowpea, more than $90 \%$ of these isolates, derived from $B$. diffusa, showed severity in cowpea equal to the $M$. phaseolina reference isolate. However, the isolates obtained from $T$. portulacastrum were less severe to cowpea when compared to the isolate from $B$. diffusa (Table 2).

Weeds are important alternative hosts of plant pathogens (NEGREIROS et al., 2019a; b; SALES JÚNIOR et al., 2019). They can actively contribute to the survival of soil-borne phytopathogenic fungi, especially during the off-season (SALES JÚNIOR et al., 2012).

The coexistence of cowpea with weeds is one of the main factors compromising the development and productivity of this crop. Thus, weeds control is considered one of the main components of the production costs (FONTES; GONÇALVES; MORAIS, 2010). According to Freitas et al. (2009), when uncontrolled, weeds can reduce cowpea grain yield by up to $90 \%$. Moreover, prior knowledge of weed participation as alternative hosts of soil-borne phytopathogenic fungi may be of great relevance in the management of root diseases, especially in the off-season, as they may play an important role in disease epidemiology (SALES JÚNIOR et al., 2012).

The weeds species $T$. portulacastrum and $B$. diffusa occur frequently in the main areas of melon (SALES JÚNIOR et al., 2019), watermelon (SILVA et al., 2013), and corn (Zea mays L.) (NASCIMENTO et al., 2011) cultivation in the state of RN, Brazil. In addition to Macrophomina spp., they have also been reported to host, Monosporascus spp. and Rhizoctonia solani Kühn, which are soil- 
borne pathogens associated with root rot and vine decline on melon crops (SALES JÚNIOR et al., 2012; NEGREIROS et al., 2019a).

Reports estimate that there are over 700 species of Macrophomina host plants in the world (FARR; ROSSMAN, 2019). In Brazil, this genus has been reported in approximately 60 species of cultivated and weed plants, with the weeds being also responsible for the survival of the pathogen in the absence of host crops in the field. Some of the most important crops are: Allium sativum L., Arachis hypogaea, Citrus sp. L., Cocos nucifera L., Coffea arabica L., Cucumis melo, Cucurbita sp., Daucus carota L., Glycine max (L.) Merr., Gossypium hirsutum, Helianthus annuus L., Jatropha gossypiifolia, Phaseolus aureus Roxb., P. vulgaris, Ricinus communis, Solanum tuberosum L., Sorghum bicolor (L.) Moench., Triticum aestivum L., V. unguiculata, and Zea mays (SALES JÚNIOR et al., 2012; MACHADO et al., 2019; NEGREIROS et al., 2019b; SALES JÚNIOR et al., 2019).

In Brazil, there are no chemicals registered for field control of this pathogen in any crop, and only products for seed treatment are available (AGROFIT, 2019). Trianthema portulacastrum and $B$. diffusa, even with no visible symptoms in the plants, when present in a cowpea production area can compete for water, nutrients and light, and also act as a source of inoculum for $M$. phaseolina and $M$. pseudophaseolina, which may cause charcoal rot in the plants and, consequently, a reduction in yield.

\section{CONCLUSIONS}

Our results emphasize the need to establish management practices aiming to control $T$. portucalastrum and $B$. diffusa from cowpea production areas, as they can act as potential sources of inoculum and survival for Macrophomina spp.

\section{ACKNOWLEDGEMENTS}

This study was partially financed by the Coordenação de Aperfeiçoamento de Pessoal de Nível Superior - Brazil (CAPES) - Finance Code 001 and by the Conselho Nacional de desenvolvimento Científico e Tecnológico (CNPq).

\section{REFERENCES}

ABAWI, G. S.; PASTOR-CORRALES, M. A. Root rots of bean in Latin America and Africa: diagnosis, research methodologies and management strategies. Cali, CO: Centro Internacional de Agricultura Tropical (CIAT), 1990. 114 p. (CIAT publication, 35).
AGROFIT. Sistema de Agrotóxicos Fitossanitários. Disponível em: http:// agrofit.agricultura.gov.br/agrofit_cons/ principal agrofit cons.>. Acesso em: 10 out. 2019.

AMBRÓSIO, M. M. Q. et al. Screening a variable germplasm collection of Cucumis melo L. for seedling resistance to Macrophomina phaseolina. Euphytica, 206: 287-300, 2015.

ATHAYDE SOBRINHO, C. Principais doenças do feijão-caupi no Brasil. In: BASTOS, E. A. (Ed.). A cultura do feijão-caupi no Brasil. 1. ed. Teresina, PI: EMBRAPA, 2016. v. 1, cap. 3, p. 44-67.

ATHAYDE SOBRINHO, C.; VIANA, F. M. P.; SANTOS, A. A. Doenças fúngicas e bacterianas. In: FREIRE FILHO, F. R.; LIMA, J. A. A.; RIBEIRO, V. Q. (Eds.). Feijão-caupi: avanços tecnológicos. 1. ed. Brasília, DF: Embrapa Informação Tecnológica, 2005. v. 1, cap. 12 , p. 462-484.

BITANCOURT, A. A. Uma nova doença do feijão. O Biológico, 1: 41, 1935.

COMPANHIA

NACIONAL $\mathrm{DE}$ ABASTECIMENTO - CONAB. Acompanhamento da safra brasileira de grãos, v. 6, Safra 2018/19 Oitavo levantamento. Disponível em: <https:// www.conab.gov.br/info-agro/safras/graos>. Acesso em: 15 de out. 2019

DAMASCENO-SILVA，K. J.; ROCHA， M. M.; MENEZES-JÚNIOR, J. A. Socioeconomia. In: BASTOS, E. A. (Ed.). A cultura do feijão-caupi no Brasil. 1. ed. Teresina, PI: EMBRAPA, 2016. v. 1, cap. 1, p. 6-12.

DHINGRA, O. D.; SINCLAIR, J. B. Biology and pathology of Macrophomina phaseolina. Viçosa, MG: Universidade Federal de Viçosa, 1978. 166 p.

FAOSTAT. FAO Statistical Databases, Food and Agriculture Organization of the United Nations. Disponível em: <www.fao.org/faostat/en/\#home>. Acesso em: 15 de out. 2019.

FARR, D. F.; ROSSMAN, A. Y. Fungal Databases, U.S. National Fungus Collections, ARS, USDA Disponível em: $\quad<$ https://nt.ars-grin.gov/ fungaldatabases $>$. Acesso em 10 de out. 2019.

FONTES, J. R. A.; GONÇALVES, J. R. P.; MORAIS, R. R. Tolerância do feijão-caupi ao herbicida oxadiazon. Pesquisa Agropecuária Tropical, 40: 110-115, 2010.

FREITAS, F. C. L. et al. Interferência de plantas daninhas na cultura do feijão-caupi. Planta Daninha, 27: 241-247, 2009. 
GOMES-SILVA F. et al. Genetic diversity of isolates of Macrophomina phaseolina associated with cowpea from Brazil semi-arid region. Journal of Agricultural Science, 9: 112-116, 2017.

GUPTA, G. K.; SHARMA, S. K.; RAMTEKE, R. Biology, epidemiology and management of the pathogenic fungus Macrophomina phaseolina (Tassi) Goid. with special reference to charcoal rot of soybean (Glycine max (L.) Merrill). Journal of Phytopathology, 160: 167-180, 2012.

KAUR, S. et al. Emerging phytopathogen Macrophomina phaseolina: biology, economic importance and current diagnostic trends. Critical Reviews in Mycrobiology, 38: 136-151, 2012.

MACHADO, A. R. et al. Bayesian analyses of five gene regions reveal a new phylogenetic species of Macrophomina associated with charcoal rot on oilseed crops in Brazil. European Journal of Plant Pathology, 153: 89-100, 2019.

NASCIMENTO, P. G. M. L. et al. Levantamento Fitossociológico das comunidades infestantes em diferentes sistemas de plantio de milho em MossoróRN. Agropecuária Científica no Semi-Árido, 7: 19, 2011.

NDIAYE, M. et al. Is the recently described Macrophomina pseudophaseolina pathogenically different from Macrophomina phaseolina? African Journal of Microbiology Research, 9: 2232-2238, 2015.

NEGREIROS, A. M. P. et al. Identification and pathogenicity of Macrophomina species collected from weeds in melon fields in Northeastern Brazil. Journal of phytopathology, 167: 326-337, 2019b.

NEGREIROS, A. M. P. et al. Prevalent weeds collected from cucurbit fields in Northeastern Brazil reveal new species diversity in the genus Monosporascus. Annals of Applied Biology, 174: 349-363, 2019a

NORONHA, M. A.; DAMASCENO-SILVA, K. J.; SILVA, S. R. Avaliação da Resistência de Genótipos de Feijão-caupi a Macrophomina phaseolina. Aracaju, SE: Embrapa Tabuleiros Costeiros, 2012. 4 p. (Comunicado Técnico 126).

RAMOS, H. M. M. et al. Estratégias ótimas de irrigação do feijão-caupi para produção de grãos verdes. Pesquisa Agropecuária Brasileira, 47: 576 $-583,2012$.

REIS, E. M.; BOARETTO, C.; DANELLI, A. L. D. Macrophomina phaseolina: density and longevity of microsclerotia in soybean root tissues and free on the soil, and competitive saprophytic ability. Summa Phytopathologica, 40: 128-133, 2014.

RIOS, G. P. Doenças fúngicas e bacterianas do caupi. In: ARAÚJO, J. P. P.; WATT, E. E. (Eds). O caupi no Brasil. 1. ed. Brasília, DF: EMBRAPA/ IITA, 1988. v. 1, cap. 19, p. 547-589.

ROCHA, M. M. et al. Controle genético do comprimento do pedúnculo em feijão-caupi. Pesquisa Agropecuária Brasileira, 44: 270-75, 2009.

SALES JÚNIOR, R. et al. Ervas daninhas como hospedeiras alternativas de patógenos causadores do colapso do meloeiro. Revista Ciência Agronômica, 43: 195-198, 2012

SALES JÚNIOR, R. et al. Weeds as potential hosts for fungal root pathogens of watermelon. Revista Caatinga, 32: 1-6, 2019.

SARR, M. P. et al. Genetic diversity in Macrophomina phaseolina, the causal agent of charcoal rot. Phytopathologia Mediterranea, 53: 250-268, 2014.

SILVA, F. A. Z.; AZEVEDO, C. A. V. The Assistat Software Version 7.7 and its use in the analysis of experimental data. African Journal Agricultural Research, 11: 3733-3740, 2016.

SILVA, M. G. O. et al. Manejo de plantas daninhas na cultura da melancia nos sistemas de plantio direto e convencional. Horticultura Brasileira, 31: 494499,2013

ZHAO, L. et al. Macrophomina vaccinii sp. nov. causing blueberry stem blight in China. MycoKeys, 55: 1-14, 2019. 